\title{
Greenhouse Gases and Energy Intensity of Granite Rock Mining Operations in Thailand: A Case of Industrial Rock-Construction
}

\author{
Suthirat KITTIPONGVISES ${ }^{1,2,3 *}$, Orathai CHAVALPARIT ${ }^{2,4}$, Chakkaphan SUTTHIRAT STI, $^{1,2}$ \\ ${ }^{1}$ Environmental Research Institute, Chulalongkorn University (ERIC), Bangkok 10330, Thailand \\ ${ }^{2}$ Research Program of Toxic Substance Management in the Mining Industry, \\ Center of Excellence on Hazardous Substance Management (HSM), Bangkok 10330, Thailand \\ ${ }^{3}$ Research Unit of Site Remediation on Metals Management from Industry and Mining (Site Rem), \\ Chulalongkorn University, Bangkok 10330, Thailand \\ ${ }^{4}$ Department of Environmental Engineering, Faculty of Engineering, \\ Chulalongkorn University, Bangkok 10330, Thailand
}

\begin{abstract}
This paper is aimed to systematically assess greenhouse gases (GHGs) and energy intensity of the granite rock mining operations in Thailand and also identify a range of feasible options to minimize their GHG emissions. Mining factories A, B and C, located in the Eastern region of Thailand, were selected as research case studies. The results indicated that the 3-year average of GHGs emissions from factories A to $\mathrm{C}$ was $3387718 \mathrm{kgCO}_{2} \mathrm{e}$ per year with approximately $2.92 \mathrm{kgCO}_{2} \mathrm{e}$ per ton of granite rock produced over 2012 to 2014 . Of this, the carbon intensity of grid-electricity consumption for the crushed rock production was 1.84 $\mathrm{kgCO}_{2} / \mathrm{kWh}$. Diesel fuel combustion for transport activities in the mining factories was the greatest contributor to GHGs emissions (68\%) compared to the purchased electricity and explosion process, with $31 \%$ and $1 \%$, respectively. In-Pit Crushing and Conveying (IPCC) installation, haul truck payload optimization and management, and reduction in tire rolling resistance have shown potential to reduce carbon emissions accounted for $20 \%$ to $70 \%$.
\end{abstract}

Keywords - Emissions; granite; greenhouse gases; industrial rock-construction; Thailand

\section{INTRODUCTION}

Thailand's mining sector is an important contributor to the country's economy [1]. During 20092013, the mining sector contributed to approximately $3.4 \%$ to $4 \%$ of Thai GDP [2]. Although tin and gemstone were vitally important minerals in the country's history, utilization of other geological resources such as limestone, lignite, basalt, granite and shale are now showing an upward trend (Table 1) [3]. Typically, the role of limestone and granite rock lies in many applications as a coarse and fine aggregate for all forms of construction, concrete, cement, railways and so on. Of this, most limestone and granite are annually used in the construction industry [4].

Apart from the economic point of view, environmental impacts from mining and mineral exploration are also significant. Like most heavy industries, mining is a major energy consumer and emitter of greenhouse gases (GHGs) which are drivers of global climate change. The overwhelming consensus among scholars is that the current global warming is primarily caused by human activities. In Thailand, TGO [5] reported that mineral production processes accounted for over $90 \%$ of total GHGs emissions from the industrial sector. There is a relationship between

* Corresponding author.

E-mail address: suthirat.k@chula.ac.th 
the processing of mineral products and climate change, related to fuel and electricity consumed by machinery in both extraction and processing [6]-[9].

A study done by [10], for instance, showed that total GHGs emission of the in-situ leaching of gold, uranium and copper extraction in Australia were about $29 \mathrm{tCO}_{2} \mathrm{e} / \mathrm{kg}$ gold, $38 \mathrm{kgCO}_{2} \mathrm{e} / \mathrm{kgU}_{3} \mathrm{O}_{8}$, and $4.78 \mathrm{kgCO}_{2} \mathrm{e} / \mathrm{kg} \mathrm{Cu}$, respectively. Similarly, [11] also reported that total carbon dioxide emissions from the uranium mining industry in Namibia, Australia, Nigeria and Canada varied from $10 \mathrm{kgCO}_{2} \mathrm{e} / \mathrm{kgU}_{3} \mathrm{O}_{8}$ to $50 \mathrm{kgCO}_{2} \mathrm{e} / \mathrm{kgU}_{3} \mathrm{O}_{8}$. Although the rapid rise in GHGs is a problem, in Thailand, there have been a limited number of studies attempting to qualify the intensity of GHGs in various industries, including mining and mineral processing.

Therefore, the aims of this study were to quantify both GHGs and energy intensity of the mining of an industrial rock-construction in Thailand and also identify potential options to reduce its carbon emissions. The quarrying of granite was selected as a case study in this research.

TABLE 1. UTILIZATION OF MinERAL RESOURCES IN THAILAND OVER 2010-2014, MiLLION TONNES [4]

\begin{tabular}{llllll}
\hline Mineral utilization & 2010 & 2011 & 2012 & 2013 & 2014 \\
\hline Limestone & 133.20 & 137.97 & 147.15 & 157.96 & 161.44 \\
Lignite & 18.11 & 20.25 & 18.19 & 18.92 & 18.45 \\
Basalt & 12.16 & 10.98 & 10.54 & 10.22 & 13.98 \\
Granite & 4.21 & 5.02 & 5.30 & 7.61 & 6.91 \\
Shale & 4.12 & 4.34 & 4.69 & 4.03 & 5.31 \\
\hline
\end{tabular}

\subsection{Thailand's Net GHGs Emissions}

In Thailand, the total net GHG emission in 2000 was about 229.08 million tonnes carbon dioxide equivalent ( $\left.\mathrm{Mt} \mathrm{CO}_{2} \mathrm{eq}\right)$ [5]. Overall, the energy sector has emerged as the largest contributor to total emissions $(69.9 \%)$, followed by agriculture, industry and the waste sector, respectively. Within the industrial sector, mining and mineral production (i.e. cement industry) in particular was the main source of emissions $(97.9 \%)$, as depicted in Fig. 1.

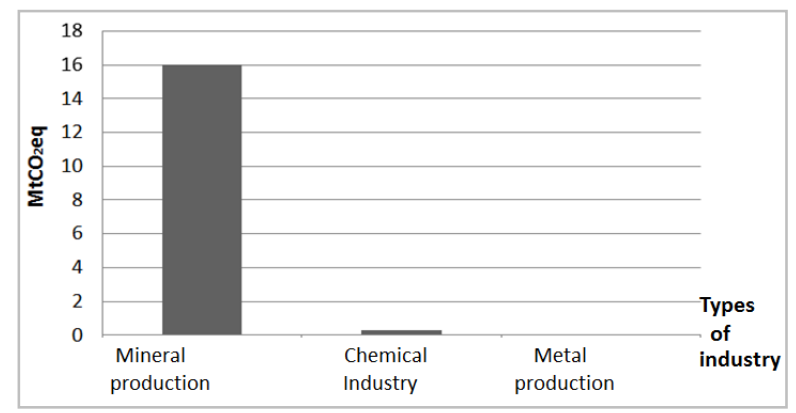

Fig. 1. GHGs emissions from the industrial sector in Thailand in 2000 [5].

\subsection{Methods for the Quantification of GHG Emissions}

There are several methods that can be applied to estimate the total amount of GHGs emissions. Comparatively, direct measurements of carbon emissions (i.e. continuous emissions monitoring, source testing, etc.) are definitely the most precise and accurate methods. However, these GHGs related data are not routinely collected or readily available. Therefore, in general, emission estimates are normally obtained by using a calculation methodology. For instance, regarding the 
GHGs protocol developed by the World Resource Intuition (WRI) and the World Business Council on Sustainable and Development (WBCSD), both direct and indirect sources of emissions are systematically considered. All types of activity data and suitable emission factors are needed to calculate total emissions. Under this scheme, it is important to choose the appropriate emission factor for each activity type. Recognizing this, [12] observed that the above mentioned method is widely used and recommended. However, meanwhile several calculation methods (i.e. life cycle assessment and benchmarking) have been developed and published to date, as follows:

Life cycle assessment (LCA) has been widely used as an analytical tool to evaluate life cycle emissions of a product, process or related activity (i.e. from the extraction of raw material to manufacture, transport, consumption and final disposal) in various industries such as food processing, textiles, energy sector, mining and mineral processing industry. Principally, the LCA method involves a systematic set of procedures that are used for examining both input and output of materials, energy and also the associated environmental impacts directly attributable to the functional unit of the product or service throughout its life cycle. For instance, [13] investigated a cradle-to-gate LCA of uranium mining and milling in Canada. All sources of GHGs emissions that fall inside the system boundary were:

- Emissions associated with mining and milling operations (i.e. electricity and fuel utilization, transportation of materials to the facility, embodied energy, etc.);

- Emissions from use of fuel in facility-owned equipment and vehicles;

- Emissions related to net electricity imports to the facility;

- Emissions from the consumption of explosives;

- Emissions from chemicals processed during mining operations;

- Emissions embodied in reagents;

- Emissions from solid and liquid wastes;

- Carbon uptake from land-use change, and so on.

However, it should be noted that the information of GHGs emissions could not be commonly used as a single indicator to present all the environmental impacts within production system and technology [14].

Beside this, benchmarking is a very broad concept that has been developed and applied to assess the performance of GHG emissions across facilities (or against a common standard). The benchmark values are basically expressed in terms of the total amount of emissions (i.e. tons $\mathrm{CO}_{2} \mathrm{e}$ ) per unit of volume or mass of material or number of units (i.e. tons, USD or other metric units). In other words, benchmarking is the comparison of performance with respect to GHGs emissions or the level of specific emissions for a certain activity. The assessment covers both direct and indirect emissions of GHGs. Many industries (i.e. cement, iron, steel, lime, glass, chemical, petroleum, pulp and paper industry) in developed countries have significant experiences with the benchmarking method and also support a benchmark based allocation methodology in the EU emission trading scheme [15]. Examples of the benchmarking scheme are: product-specific emission benchmark, technology-specific emission benchmark, input - specific emission benchmark, and fuel-specific emission benchmark. To illustrate, [16] applied the concept of process benchmark to evaluate both energy efficiency and potential for energy consumption reduction in the brewery industry. This approach, additionally, can be a possible solution for applying process benchmarks for several industries that produce different types of products at the same reference level. As noted, the benchmark values are either specified at the country or regional level, depending on their data availability. 


\section{MATERIALS AND METHODS}

Method of estimating GHGs emissions in this study comprised the steps of i) selecting case study factories and determining GHGs emission boundaries, and ii) quantifying GHGs emissions from case factories, as follows:

\subsection{Case Studies}

In Thailand, geographically, the potential of mineral reserves are located in various regions of the country. In this context, [17] reported that the locations of granite were lineated in the three major belts, from the East to the West, the Central Belt Granites and the Eastern Belt Granites. As depicted in Fig. 2, three factories (A-C) located in the Eastern region of Thailand (approximately 80 kilometers east of Bangkok) were selected as research case studies. The processing of granite (industrial rock-construction) was further presented in section 3.

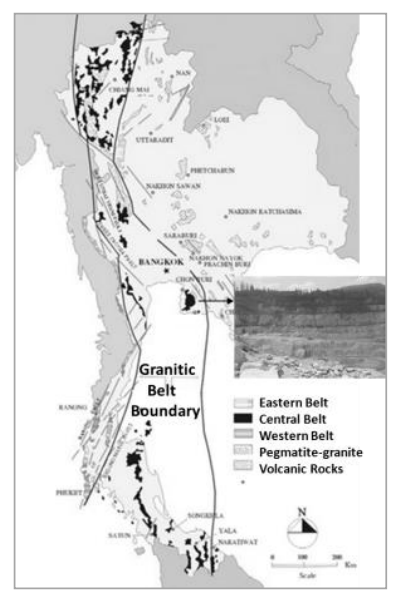

Fig. 2. Distribution pattern of the granitic rocks in Thailand (modified from [17]) and research case studies in the eastern region of the country.

\subsection{Boundaries of GHGs Emissions}

In estimating the GHGs emissions from the granite rock mining operation, sources of GHGs emissions can be divided into 3 scopes [18], [19]:

- Scope 1-Direct emission: GHGs emissions from sources that are owned by the entity (i.e. emissions from industry primarily involve fossil fuels burned on-site: stationary emission, emissions from entity-owned vehicles: mobile emission, etc.);

- Scope 2 - Indirect emission: Indirect emissions result from the purchase of gridelectricity, heat, or steam consumed but not directly generated by the entity;

- Scope 3 - Other indirect emissions: Emissions are a consequence of the activities of the factory but that occur from sources not operated by the factory. For instance, employee commuting, contracted solid waste disposal, wastewater treatment, etc.

Within the project boundary, only scope 1 and scope 2 are accounted in this study. All raw materials used for both granite extraction and transportation of crushed stone materials were included in the estimation. The sources of GHGs emissions and assessment boundaries were shown in Fig. 3. As a representative of the data, the 3-year average (2012-2014) was presented. 


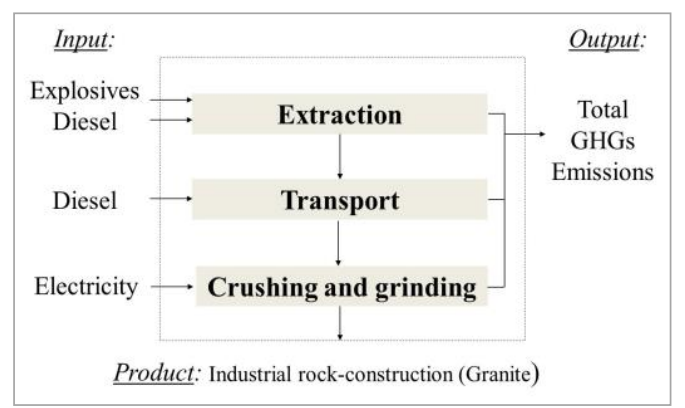

Fig. 3. Scope of GHGs emissions from the granite rock mining operation.

The quantification of GHGs emitted from all potential sources can be done by the following approach [18], [19]:

\subsubsection{Direct emissions from mobile combustion source}

Eq. (1) can be used to estimate the amount of direct emissions $\left(\mathrm{tCO}_{2} \mathrm{e}\right)$ from transport-related combustion of fuels or mobile combustion activities.

where

$$
\text { Emissions }=\text { Quantity of fuel combusted }{ }_{a b} \cdot E F,
$$

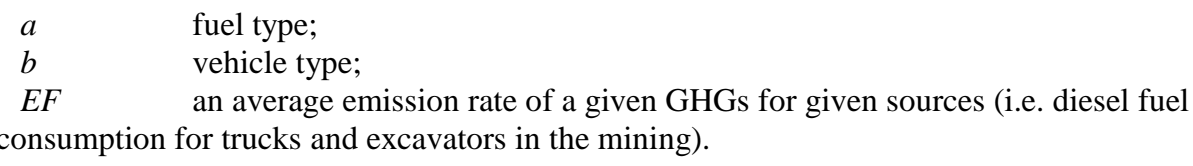

\subsubsection{Direct emissions from industrial processes (non-combustion activities)}

During the mining process, direct emissions $\left(\mathrm{tCO}_{2} \mathrm{e}\right)$ from non-combustion activities can be estimated based mainly on the amount of blasting agent used. The $E F$ of an explosive mixture (ammonium nitrate / fuel oil: ANFO) of 0.189 ton of $\mathrm{CO}_{2}$ per ton of ANFO [20] was applied in this study (Eq. (2)).

$$
\text { Emissions }=\text { Amount of explosives used }(\mathrm{kg}) \cdot E F \text {, }
$$

where $E F$ is emission factor of the detonation of explosives.

\subsubsection{Indirect emissions from the consumption of purchased electricity}

Eq. (3) can be used to estimate the amount of indirect GHGs emissions $\left(\mathrm{tCO}_{2} \mathrm{e}\right)$ associated with purchased electricity from the grid.

$$
\text { Emissions }=\text { Quantity of electricity consumption }(\mathrm{kWh}) \cdot E F,
$$

where $E F$ is emission factor of grid electricity.

Regarding Eq. (1-3), the net GHGs emissions were estimated by multiplying all activity data with their relevant $E F$ issued by the Thailand Greenhouse Gas Management Organization (TGO). Based on a 3-year average, estimated emissions were expressed in the unit of "kilogram carbon dioxide equivalent $\left(\mathrm{kgCO}_{2} \mathrm{e}\right)$ " and " $\mathrm{CO}_{2}$ emissions per ton of rock product $\left(\mathrm{kgCO}_{2} \mathrm{e} /\right.$ ton of product)" for GHGs intensity. 


\section{Results AND Discussion}

\subsection{Granite Rock Quarrying Process}

The following four steps of the granite rock quarrying include site preparation, mining, transport and comminution:

Site preparation: Site preparation involves the process of preparing the prospect area for mining and also constructing a mining infrastructure to support the facility.

Drilling and blasting: Drilling is a primary means of extracting granite rock at mining operations. Truck or drifter drills are used to make horizontal boreholes up to $12 \mathrm{~m}$ in depth. After that, blasting is accomplished by discharging an explosive confined in a borehole. The most common blasting agent is ammonium nitrate fuel oil (ANFO), which consists of ammonium nitrate mixed with fuel oil (about 5 to 6 percent by weight).

Digging up and transport: After breaking the granite outcrop, the broken granite blocks are then transported from the mine site to the processing plant by heavy duty diesel trucks.

Comminution: Comminution (crushing and grinding) is done to break the granite block into particles as small as desired range of grain sizes. The mined rocks are hauled to the stockpile by heavy duty truck and fed into primary crushing machine (i.e. Jaw crusher). As secondary crushing, the crushed rocks are transferred to impact crusher or cone crusher. After the crushing process, crushed rocks are then sieved into different grade by vibrating screen, or are returned to the crusher machine for re-crushing.

In estimating the GHGs emissions, Fig. 4 presents the diagram of granite quarrying operations and also the potential sources of emissions. Direct emissions come from both on-site fuel combustion, such as diesel engines used in heavy vehicles and emissions from industrial processes, such as explosives used in the mining operations. Indirect GHGs emissions are associated with the purchase of electricity from the grid. In terms of productivity, the average value of granite rock production of all case factories ranked approximately (816 201 to 2000000 ) tons/year.

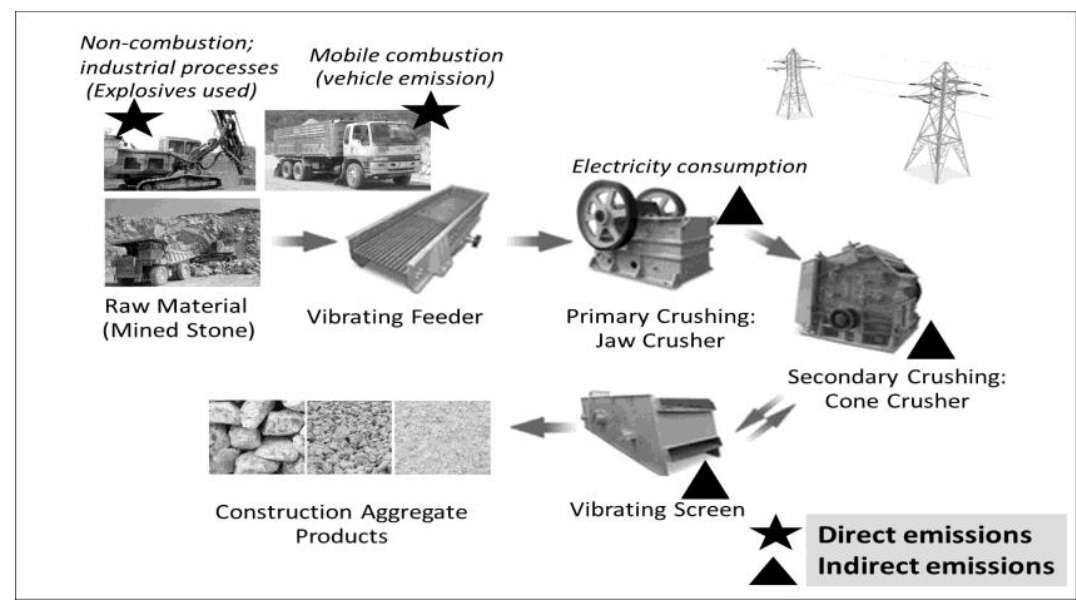

Fig. 4. Process diagram for granite mining operations and potential sources of GHGs emissions. 


\subsection{Electricity and Diesel Fuel Consumption}

Diesel is a signification energy source for mining and quarrying operations. It is typically used for the transport process (i.e. the hauling of ore and overburden). The average amount of diesel fuel consumed by trucks of factories A, B and C were approximately 1.94, 1.07 and 3.57 liters per ton product, respectively. Over 2012 to 2014, annual electricity consumption of all factories ranged between (2.29 to 6.07$) \mathrm{kWh}$ per ton product (Table 2).

\subsection{Explosives Used in the Mining Processes}

Factories A, B and C consumed approximately $0.20 \mathrm{~kg}$ to $0.75 \mathrm{~kg}$ ANFO per ton product over 2012 to 2014, as depicted in Table 2.

TABle 2. AVERAge Diesel Fuel AND EXPlosives Used Per Ton Product Over 2012 to 2014

\begin{tabular}{lll}
\hline Case Factories & $\begin{array}{l}\text { Average diesel fuel consumption, } \\
1 / \text { ton product }\end{array}$ & $\begin{array}{l}\text { Average ANFO consumption, } \\
\mathrm{kg} / \text { ton product }\end{array}$ \\
\hline $\mathrm{A}$ & 1.94 & 0.67 \\
$\mathrm{~B}$ & 1.07 & 0.20 \\
$\mathrm{C}$ & 3.57 & 0.75 \\
\hline
\end{tabular}

\subsection{Quantification of GHGs Emissions}

GHGs emissions generated by granite mining operations can be estimated based on the quantity of substance going in and out of an entire process of crushed rock production per annum. As shown in Fig. 5, all GHGs emissions associated with the organizational boundary operations are: (i) extraction, (ii) transportation, and (iii) comminution (i.e. crushing and grinding).

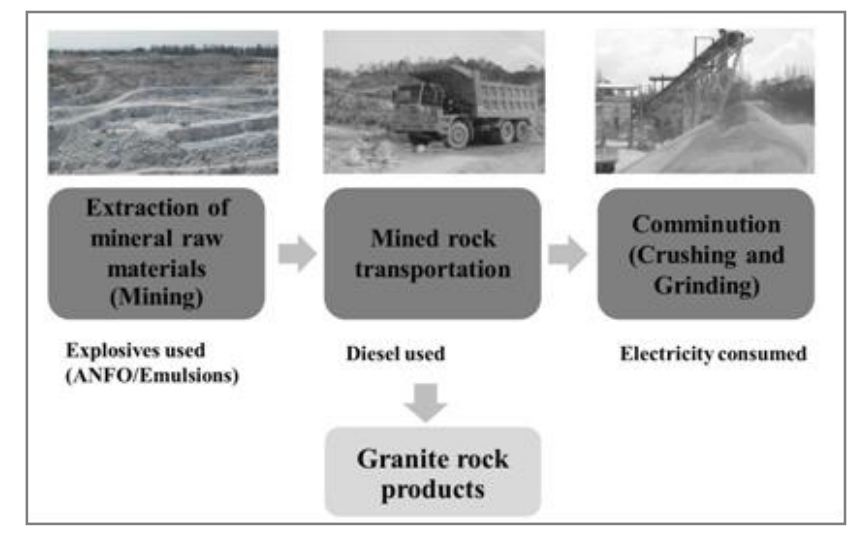

Fig. 5. Sources of GHGs emissions and organizational boundaries.

As mentioned earlier, this study considered only scopes 1 and 2 of GHGs emissions. The total emissions (both direct and indirect sources) were estimated by applying the appropriate EFs issued by [21], [22] calculated in Eq. (1-3). For instance, the $E F$ of $2.7446 \mathrm{kgCO}_{2} \mathrm{eq} / 1$ and $0.581 \mathrm{kgCO} 2 \mathrm{eq} / \mathrm{kWh}$ used to estimate the emissions of GHGs from mobile combustion and purchased grid electricity, respectively [21], [22]. For an explosive mixture, an $E F$ of 0.189 ton of $\mathrm{CO}_{2}$ per ton of ANFO issued by [23] also used. The calculated results found that total GHGs emissions of mining factories A, B, and $\mathrm{C}$ over 2012 to 2014 were approximately (3747 497; 2877 099; and 3538 557) $\mathrm{kgCO}_{2} \mathrm{e}$ per year, 
respectively (3.38 $\mathrm{tCO}_{2} \mathrm{e}$ per year of an average). As evident in Fig. 6, GHGs emission from transport activities was by far the largest share (68\% of total emissions). In other studies, comparatively, the estimated GHGs emissions from limestone, gold, and lignite mining in Thailand were approximately (20 878; 36 886, and 571539 ) $\mathrm{tCO}_{2}$ e per annual mine production, respectively [20]. In terms of the carbon intensity, in this study, the average emissions of about $2.92 \mathrm{kgCO}_{2} \mathrm{e}$ per ton product of all mining factories were within the range of other international studies $\left(0.27\right.$ to $4.32 \mathrm{kgCO}_{2} \mathrm{e}$ per ton of mining product) [24]-[28] (Table 3).

\subsection{Embodied Energy}

In this study, the term "embodied energy" refers to the total energy required for the production of granite aggregate (i.e. extraction and manufacturing). Under this scheme, the value of embodied energy value is typically expressed as the amount of electricity consumed per unit of rock production ( $\mathrm{kWh} /$ ton of product). As depicted in Table 3, by calculation, it was found that electricity consumption for crushed rock production of this research was also within the range of the previous study (1.76 to $9.70 \mathrm{kWh} /$ ton of product) [27].

TABLE 3. GHGs EMission InTEnsity of the CRUShed Stone PROCESSING

\begin{tabular}{lll}
\hline Type of mining & $\begin{array}{l}\text { Carbon intensity, } \\
\mathrm{kgCO}_{2} \mathrm{e} / \text { ton of product }\end{array}$ & $\begin{array}{l}\text { Embedded energy, } \\
\mathrm{kWh} / \text { ton of product }\end{array}$ \\
\hline Crushed rock aggregate & $1.21[24]$ & $9.70[27]$ \\
& $1.42[25]$ & \\
& 3.70 to $3.80[26]$ & \\
& $4.32[27]$ & \\
Ready mixed concrete & $0.95[27]$ & $1.76[27]$ \\
Hard rock quarrying & 1.48 to $2.52[28]$ & $8.30[27]$ \\
Sand and gravel quarrying & 0.27 to $2.39[28]$ & \\
& $4.28[27]$ & 4.54 \\
This study & 2.92 & \\
\hline
\end{tabular}

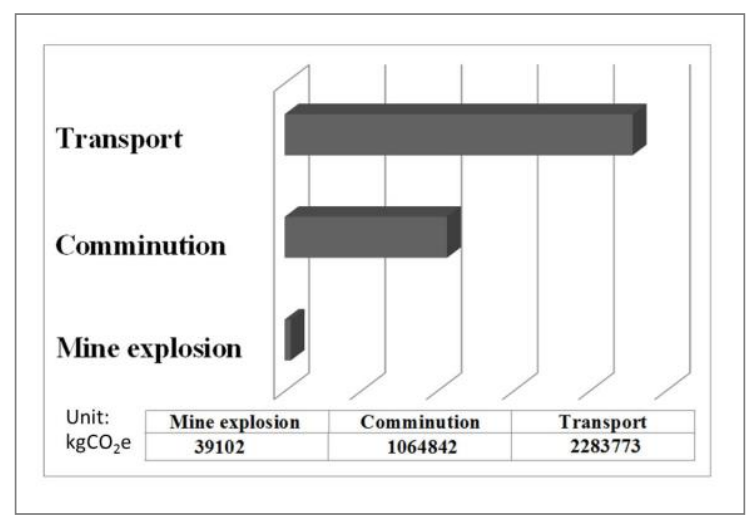

Fig. 6. Average GHGs emissions of case study factories over 2012-2014 by main sources.

The distribution of GHGs emissions by scope clearly shows that $\mathrm{CO}_{2}$ dominated scope 1 direct emission (68\%). Those emissions came principally from the diesel engine combustion during the mining operations. Approximately $31 \%$ of the total emissions came directly from electricity consumption for mining and processing, as the second largest source. In the meanwhile, the 
blasting process generated the lowest GHGs emissions (1\%). Compared to other mines (i.e. gold), because of different mining methods, the results of the current analysis are inconsistent with some previous studies. In a sense, [7], [29], [30] reported that the utilization of electricity for mineral processing and mining operation was the largest contributor to total carbon emissions. Of this total, more than 50 to 80 percent of total electricity was used for crushing and grinding processes of gold mining [29]-[31].

\subsection{Potential Options for GHGs Reduction}

As pointed out earlier, transport operations in granite mining were considered to be the largest contribution of emissions compared to other sources. Principally, there are a number of technological and potential of mitigation options to reduce GHG emissions during mining operations:

\subsubsection{In-pit crushing and conveying (IPCC)}

IPCC refers to the use of fully mobile, semi-mobile primary crusher close to the extraction site, or fixed in-pit crushers with a conveyor system to transport material out of the pit to further processing steps. Compared to conventional truck and shovel operations, IPCC technology can potentially reduce annual GHGs emissions by (38 to 150 000) ton $\mathrm{CO}_{2} \mathrm{e}$ [28]-[32]. This associated emissions reductions would be also reduce an operation cost approximately (0.18 to 0.25$)$ US $\$$ ton [28].

\subsubsection{Haul truck payload management}

Improving the efficiency of haulage systems is considered to be one of the great challenges in the mining industry [33], [34]. A study done by [35] indicates that the emission of $\mathrm{CO}_{2}$ is directly proportional to the diesel fuel consumption. There, in this context, is a decrease in fuel consumption when mine operators move to larger trucks that have more efficient engines. For instance, the total $\mathrm{CO}_{2}$ emissions decreased by approximately $21.4 \%$ when moving the truck payload from 154 ton to 218 ton of load-carrying capacity.

\subsubsection{Reduction in rolling resistance of vehicle tires}

Another analysis on rolling resistance done by [36] highlights that decreased total rolling resistance of vehicle tires results in decreased cycle time and has a positive effect on $\mathrm{CO}_{2}$ emissions. Given 2883 meters one-way haul distance on surface ground and also 7.4 minutes of loading, dumping and waiting time, decreased rolling resistance from $10 \%$ (poor road) to $8 \%$ and $4 \%$ (good road) would reduce $43 \%$ and $70 \% \mathrm{CO}_{2}$ emissions, respectively, for CAT777.

\section{CONCLUSION AND IMPLICATIONS}

Global climate change is one of the most important environmental issues of our time. Reducing carbon emissions is also one of our society's greatest challenges. This study is aimed to estimate the amount of GHGs emitted from the mining of granite rock in Thailand and also appropriately identify a range of feasible options to lower their carbon emissions. Granite mining factories, located in the eastern region of Thailand, were selected as research case studies. Estimated results found that burning of diesel fuels associated with transportation was by far a major source of energy-related GHGs emissions in the mining industry. Potentially, possible technological options for emissions reduction from transportation include i) in-pit crushing and conveying (IPCC), ii) haul truck payload management, and iii) reduction in tire rolling resistance. In doing so, mine operators have to consider both the costs and benefits of GHG emission reduction in a measurable, 
reportable, and verifiable (MRVs) manner. Importantly, the authors recommended that further studies are needed to develop a comprehensive method for analysing the status of low carbon society (i.e. combined methodology to evaluate the low-carbon transition [37]) and also conduct feasibility study for the application of low carbon technologies [38] in the industrial sector. It may be necessary to investigate the application of integrated methods that can be used to develop sustainable energy production systems (i.e. energy, exergy and emergy analysis [39]) in both the industrial and energy sectors in Thailand.

\section{ACKNOWLEDGEMENT}

The authors thank the Ratchadaphiseksomphot Endowment Fund, Chulalongkorn University (Research Grant for New Scholar), the Office of Higher Education Commission (OHEC) and the S\&T Postgraduate Education and Research Development Office (PERDO) for the financial support of the Research Program and thanks the Ratchadaphiseksomphot Endowment Fund, Chulalongkorn University for the Research Unit. The authors would like to express our sincere thanks to the Environmental Research Institute (ERIC) and the Center of Excellence on Hazardous Substance Management (HSM) Chulalongkorn University for their invaluable supports in terms of facilities and scientific equipment. The authors also wish to express their special thanks to the experts of the Department of Primary Industries and Mines for their kind support and assistance.

\section{REFERENCES}

[1] Thailand's economic condition in 2010. Bank of Thailand, 2010.

[2] The Office of SMEs Promotion. SMEs white paper.

[3] Department of Primary Industries and Mines. Status of mineral resources utilization in Thailand in 2013-2014 [Online]. Available: http://www.dpim.go.th/articles?catid=127

[4] Department of Primary Industries and Mines. Mineral Statistics of Thailand (Fiscal Year) 2014-2015 [Online]. Available: http://www1.dpim.go.th/dt/pper/000001437122620.pdf

[5] TGO. GHG emission by sector in CO2 equivalent (Million tons) and percent for 2000 [Online]. Available: http://www.tgo.or.th/english/index.php?option=com_content\&view=article\&id=45\&Itemid=71

[6] East Sussex, South Downs and Brighton \& Hove. Information Paper 9 Climate Change and Waste and Minerals [Online]. Available: http://www.eastsussex.gov.uk/NR/rdonlyres/1459A461-10CA-48D0-86C2D3B558BD70AC/0/information_paper_9.pdf

[7] Norgate T., Haque N. Using life cycle assessment to evaluate some environmental impacts of gold production. Journal of Cleaner Production 2012:29-30:53-63. doi:10.1016/j.jclepro.2012.01.042

[8] Liu F., Cai Q., Chen S., Chen S., Zhou W. A comparison of the consumption and carbon emissions for different modes of transportation in open-cut coal mines. International Journal of Mining Science and Technology 2015:25:261-266. doi:10.1016/j.ijmst.2015.02.015

[9] Morrow III W. R., Hasanbeigi A., Sathaye J., Xu T. Assessment of energy efficiency improvement and CO2 emission reduction potentials in India's cement and iron \& steel industries. Journal of Cleaner Production 2014:65:131-141. doi:10.1016/i.jclepro.2013.07.022

[10] Haque N., Norgate T. The greenhouse gas footprint of in-situ leaching of uranium, gold and copper in Australia. Journal of Cleaner Production 2014:84:382-390. doi:10.1016/j.jclepro.2013.09.033

[11] Mudd G. M., Diesendorf M. Sustainability of uranium mining and milling: toward quantifying resources and ecoefficiency. Environmental Science and Technology 2008:42:2624-2630. doi:10.1021/es702249v

[12] Gao T., Lui Q., Wang J. A comparative study of carbon footprint and assessment standards. International Journal of Low-Carbon Technologies 2013:9(3):237-243. doi: 10.1093/ijlct/ctt041

[13] Parker D. J., McNaughton C. S., Sparks G. A. Life cycle greenhouse gas emissions from uranium mining and milling in Canada. Environmental Science \& Technology 2016:50:9746-9753. doi:10.1021/acs.est.5b06072

[14] Turconi R., Boldrin A., Astrup T. F. Life cycle assessment (LCA) of electricity generation technologies: Overview, comparability and limitations. Renewable and Sustainable Energy Review 2013:28:555-65. doi:10.1016/j.rser.2013.08.013

[15] Stockholm Environment Institute. Issues and Options for Benchmarking Industrial GHG Emissions. SEI White Paper, 2010.

[16] Zogla L., Zogla G., Beloborodko A., Rosa M. Process benchmark for evaluation energy performance in breweries. Energy Procedia 2015:72:202-208. doi:10.1016/j.egypro.2015.06.029 
[17] Department of Mineral Resource. http://www.dmr.go.th/main.php?filename=GeoThai_En

[18] EPA's Greenhouse Gas Emission Reductions. Available: https://www.epa.gov/climatechange/reducing-greenhousegas-emissions

[19] EPA. Quantifying Greenhouse Gas Emissions from Key Industrial Sectors in the United States: Working Draft, 2008.

[20] Department of Primary Industries and Mines, Ministry of Industry and Faculty of Engineering, Chiang Mai University, Thailand. An evaluation of CDM project development in the mining industry: Final report, 2010.

[21] TGO. Carbon Footprint for Organization: Emission factor [Online]. Available: http://thaicarbonlabel.tgo.or.th/download/Emission_Factor_CFO.pdf, Jan, 2014

[22] TGO. Carbon Footprint of Products: Emission factor [Online]. Available: http://thaicarbonlabel.tgo.or.th/download/Emission_Factor_CFP.pdf

[23] Mining Association of Canada. Inventorying, Measuring and Reporting on Climate Change Actions. Report, Pembina Institute and Stratos Inc, 2000.

[24] Weiland C. D., Muench S. T. Life cycle assessment of Portland cement concrete interstate highway rehabilitation and replacement, Report WA-RD744.4. Olympia, WA: Washington State Department of Transportation, Olympia, 2008.

[25] Stripple H. Life Cycle Assessment of Road: A Pilot Study for Inventory Analysis. Stockholm: IVL Swedish Environmental Research Institute, 2001.

[26] Mineral Products Association. Carbon Management. Available: http://www.mineralproducts.org/sustainability/carbon-management.html

[27] Mitchbell C. J. Aggregate carbon demand: the hunt for low carbon aggregate. Presented at 16th extractive industry geology conference, Portsmouth, England, 2012.

[28] Cresswell D. Quantificated report on energy consumption due to inefficient energy use. EE-Quarry Project, 2011.

[29] Yahaya N. R., Murad M., Morad N., Fizri F. F. A. Environmental impact of electricity consumption in crushing and grinding processes of traditional and urban gold mining by using life cycle assessment (LCA). Iranica Journal of Energy \& Environment 2012:3:66-73. doi:10.5829/idosi.ijee.2012.03.05.11

[30] Boyan R., Peter S. Preliminary GHG Emission Inventory. Sofia: DPM Krumovgrad, 2014.

[31] Kittipongvises S. Feasibility of Applying Clean Development Mechanism and GHG Emissions Reductions in the Gold Mining Industry: A Case of Thailand. Environmental and Climate Technologies 2012:15:34-47. doi:10.1515/rtuect-2015-0004

[32] Valery W. Improving the resource and eco-efficiency of mining operations. Metso Process Technology \& Innovation, 2014.

[33] Limsiri C. Optimization of loader-hauler fleet selection. European Journal of Scientific Research 2011:56:266-271.

[34] Ercelebi S., Bascetin A. Optimization of shovel-truck system for surface mining. The Journal of the Southern African Institute of Mining and Metallurgy 2009:109:433-439.

[35] Leslie D. R. Diesel emissions evaluation for the surface mining industry. Available: http://www.smartmines.com/diesel/DiesEm.htm

[36] Adey E., Wall F., Shail R., Kreech J., Neal W, Limprasert R., Roba C., Delmore C. Best practice for reducing the carbon footprint of the mining industry, 2011.

[37] Kalnins S.N., Blumberga D., Gusca J. Combined methodology to evaluate transition to low carbon society. Energy Procedia 2015:72:11-18. doi:10.1016/j.egypro.2015.06.003

[38] Barisa A., Rosa M., Laicane I., Sarmins R. Application of low-carbon technologies for cutting household GHG emissions. Energy Procedia 2015:72:230-237. doi:10.1016/j.egypro.2015.06.033

[39] Cimdina G., Timma L., Veidenbergs I., Blumberga D. Methodologies used for scaling-up from a single energy production unit to state energy sector. Environmental and Climate Technologies 2015:15:5-21. doi:10.1515/rtuect-2015-0002

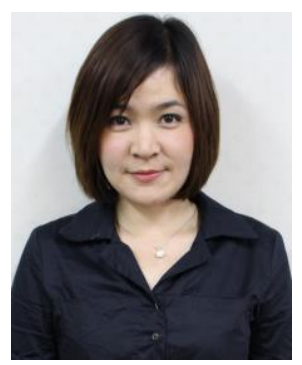

Dr. Suthirat Kittipongvises is currently a lecturer at Environmental Research Institute, Chulalongkorn University (ERIC), Thailand. She earned a PhD in Sustainability Science from the Graduate Program in Sustainability Science, Graduate School of Frontier Sciences, the University of Tokyo, Japan in 2013. She also has received her master degree on Environmental Engineering and Management, Asian Institute of Technology (AIT), Thailand in 2008. Her research focuses on climate change mitigation, GHGs quantification, carbon capture and storage, and so on. Furthermore, she has attended and presented her research at various conferences including International Climate Change in Copenhagen, Denmark in 2009, International Conference of Climate Change and Global Warming (ICCCGW), Venice, Italy in 2011, International Conference on Sustainability Science (ICSS), Arizona, USA in 2012, International Conference on Ecology, Ecosystems and Climate Change, Athens, Greece in 2013, International Expert Dialogue on Applying Resilience Concept for Climate Change Study and Disaster Management in Thailand Context, Bangkok, Thailand in 2014, and International Conference on Environmental Science and Development, Amsterdam, Netherland in 2015. E-mail: suthirat.k@ chula.ac.th. 


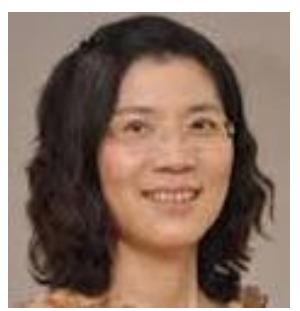

Associate Professor Orathai Chavalparit is now an instructor at Department of Environmental Engineering, Chulalongkorn University, Thailand. She has received her Ph.D. in Environmental Science from Wageningen University, Netherland. She earned a Master of Science in Environmental Biology, Mahidol University, Thailand and also got a Bachelor of Science in Biology from Chulalongkorn University, Thailand. Accordingly, her research interests focus on the topics of environmental policy and management, climate change mitigation, measurement, reporting and verification (MRV), clean technology, industrial pollution control, and so on.

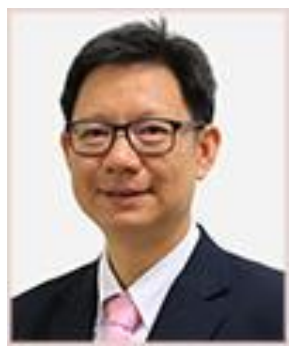

Associate Professor Dr.Chakkaphan Sutthirat is currently director of Environmental Research Institute, and also an instructor at Geology Department, Faculty of Science, Chulalongkorn University in Thailand. He has received his Ph.D. in Geology from University of Manchester, United Kingdom. He also earned DGemG (Color Stone) from the German Gemmological Association, Germany. Besides this, he received his Master and Bachelor of Science in Geology from Chulalongkorn University, Thailand. Specifically, he has expertise in Petrology, Mineralogy, Geochemistry, etc. 